\title{
A post-occupancy evaluation study of a mixed-income gated community in Cibubur, West Java, Indonesia
}

Gated communities (GCs) have been demonized as a malicious form of urban segregation because they provide a secure neighbourhood and exclusive facilities. The objective of the Indonesian government policy related to balanced housing is to create mixed-income housing in order to foster interaction between social classes in neighbourhoods and reduce the alarming social gap. This study seeks to validate the occurrence of social interaction among different economic strata in a mixed-income GC. To understand social interaction among its residents, the reasons why residents from different economic strata selected their housing are examined. The research methodology includes a post-occupancy evaluation in a mixed-income GC in Cibubur, West Java, Indonesia, an area known for its high quality neighbourhoods and facilities. This study identifies security as a major housing preference factor for many people living in a mixed-income GC. However, the reduced exclusivity of such facilities decreases their usage frequency, giving rise to trans-cluster social interaction within the same class. This finding contradicts the objective of the balanced housing policy because the residents interact with others in a similar social class beyond the segregated walls of the housing clusters.

Keywords: housing preference, balanced housing, mixed-income, secure neighbourhood 


\section{Introduction}

Gated communities (GCs) have existed in housing, urban design, and planning discourse since the twentieth century. Over the last three decades, GCs have emerged as the prevalent housing development worldwide (McKenzie, 2003), and they are now found in the Americas (Caldeira, 2000; Salcedo \& Torres, 2004), Asia (King, 2004; Wu \& Webber, 2004), Europe (Gooblar, 2002), Australia (Burke \& Sebaly, 2001), and Africa (Kuppinger, 2008). They are the re-emergence of ancient cities from early human civilization (Low, 2001; Landman \& Schonteich, 2002; Quintal, 2006), such as Jericho (Dupuis \& Thorns, 2008), the Forbidden City in Beijing (Wu, 2005), traditional cities in the Arab world (Glasze \& Alkhayyal, 2002), medieval cities in Europe, and colonial cities around the world (Blakely \& Snyder, 1997). They symbolize massive security measures, feudal aristocrats in the Middle Ages, and economic power (Bekleyen \& Dalkılıç, 2011).

The GC has been defined as self-segregating social groups that opt to live in homogenous enclaves with a certain type of lifestyle (Parker, 2006) and protect themselves from urban crime (Harvey, 1999) within surrounding walls and secure entrances (Low, 2003). Grant and Mittelsteadt (2004) also define the $\mathrm{GC}$ as a residential development with private roads closed to general traffic and with gates at primary entrances. The distinctive characteristics that separate GCs from ordinary neighbourhoods are security and barrier features, the functions of an enclosure, the facilities and amenities included, the type of residents, location, size, tenure, and policy context. Atkinson and Flint (2004) define the GC as people who take collective responsibility by behaving according to shared codes, which are characterized by legal agreements. Blakely and Snyder (1997) divide GCs into three types in terms of the degree of facilities, exclusivity, and security. The first type relates to the leisure lifestyle, reflected in various recreational amenities and other facilities that are available. It is driven by new lifestyle and consumption patterns due to globalization, which prioritizes self-interest (Caldeira, 1996). The second type corresponds to the prestigious community, which is reflected in the size of the house, and which includes certain services to maintain privacy. The third highlights layered security, which is manifested in the demand for security and safety. GCs promise a secure, privileged, and prestigious life (Erkip, 2003) in addition to eliminating the free use of amenities and decreasing property value (Le Goix, 2005) through the existence of security and surrounding walls (Low, 2003).

\subsection{Aims of the study}

The development of GCs in Indonesia began in the 1980s with the development of new towns in the areas surrounding Jakarta (Winarso, 2005). This is a result of peri-urbanization to meet the interests of wealthy individuals (Winarso et al., 2015) as well as reinforced spatial segregation (Firman, 2004). GCs polarize the social class in the exclusive residential area by minimizing interaction with the surrounding neighbourhood, especially with low-income residents (Firman, 2004).

In the 1980s, the national government began promoting foreign direct investment to boost economic growth (Leaf, 1994). Consequently, Jakarta experienced a property boom until the mid-1990s, and property prices tripled every year during that time span (Leaf, 1993). Housing development in the form of GCs rapidly expanded to surrounding cities and regencies such as Depok City, the Bogor Regency, Bogor City, Tangerang City, South Tangerang City, the Tangerang Regency, Bekasi City, and the Bekasi Regency. According to Pribadi and Pauleit (2016), the size of overall housing development reached approximately 200,000 hectares $\left(20 \mathrm{~km}^{2}\right)$ by the 1980s, and Kartiwa (2016) reports that GCs in the Greater Jakarta Metropolitan Area cover approximately $4.4 \mathrm{~km}^{2}$. Therefore, GCs have accounted for around 25\% of the total housing development in the Greater Jakarta Metropolitan Area since the 1980s.

A study by Leisch (2002) concludes that GCs in the Greater Jakarta Metropolitan Area are the result of an increasing number of insecure affluent citizens, who demand security to protect their prestigious lifestyles, in addition to religious and ethnic differences. In contrast, a study by Ginting and Sakinah (2018) in Surabaya (Indonesia) proved the absence of socioeconomic or racial segregation in GCs because the gates and surrounding walls simply provide security. Other studies of GCs in Indonesia highlight the emerging phenomenon of GCs in an urban context (Dick \& Rimmer, 1998; Leisch, 2002), the typology of GCs, the utilization of surveillance technology for warranted security (Hishiyama, 2010), location (Ahmadi, 2005; Febby, 2010), the property market (Aris, 2003; Rudiawan, 2008), and people's preference for living in a GC (Nurhadi, 2004; Tambunan, 2009; Handoko, 2011; Sueca \& Fitriani, 2012). However, the relationships between housing preferences and the level of satisfaction of GC residents remain understudied.

Several housing clusters in GC complexes have various types of houses for creating a mixed-income neighbourhood, with a required ratio of 123 for low-income, middle-income, and high-income since the enactment of Housing and Settlement Act 1/2011, Government Regulation 14/2016, and Ministry of Public Housing Decree 10/2012 on balanced housing. This 
policy regulates the number of high-, middle-, and low-income housing units in each housing complex. It is intended to create social harmony among the different economic strata of the community and transfer the obligation of the government to the private sector in low-income housing provision programs due to limited resources. Following the enactment of these regulations, the private sector in Indonesia has been obligated to build mixed-income GCs. However, the enactments have failed to achieve the expected results due to ever-increasing property prices, which burden the private sector to provide low-income housing inside mixed-income GCs. As a result, since 2015, the government has permitted the private sector to build GCs with low-income housing separately on the outskirts of the city by enacting Ministry of Public Housing Decree $7 / 2013$, where land prices are still reasonable enough to provide affordable housing for low-income citizens. According to the new regulation, unbalanced housing in GC developments has been mushrooming in the Greater Jakarta Metropolitan Area.

According to many scholars, this regulation diminishes the expected social interaction between different economic strata in society. Despite all doubts, does social interaction among different economic strata occur in mixed-income GCs? If not, why? How do the different economic strata arise in a mixed-income GC? This study seeks to validate the occurrence of social interaction among different economic strata in a mixed-income GC and to understand why social interaction occurs in a mixed-income GC. The results of the study will contribute to improving housing policy in Indonesia with regard to the correlation between mixed-income GC and social interactions between different economic strata.

\section{Literature review}

\subsection{The negative implications and positive contributions of GCs}

The rise of GCs in the US was caused by escalating racial conflict, urban violence, and social inequalities, and was related to accommodating the exodus of the white middle class in the 1980s (Sandercock, 2003). However, some scholars state that the rise of the neoliberal economy in the same period (Leisch, 2002; Hackworth, 2007; Remali \& Sala$\mathrm{ma}, 2016)$ contributed to the mushrooming of GCs all over the globe, including in Argentina (Thuillier, 2005), Chile (Salcedo \& Torres, 2004), Brazil (Coy \& Pohler, 2002), Saudi Arabia (Glasze \& Alkhayyal, 2002; Glasze et al., 2006), Ghana (Asiedu \& Arku, 2009), South Africa (Breetzke \& Cohn, 2013), Bulgaria (Stoyanov \& Frantz, 2006), Canada (Townshend, 2006), England (Blandy, 2006), Indonesia
(Leisch, 2002), Vietnam (Pow, 2009), Qatar (Rizzo, 2014; Zaina et al., 2016), Lebanon (Glasze \& Alkhayyal, 2002), Portugal (Raposo, 2006), New Zealand (Dupuis \& Thorns, 2008), Australia (Gleeson, 2006), and even in communist countries such as China (Lee \& Webster, 2006; Pow, 2007a, 2007b) and in post-communist countries such as Estonia (Ruoppila \& Kaehrik, 2003), Russia (Blinnikov et al., 2006), Bulgaria (Stoyanov \& Frantz, 2006; Hirt, 2012), Romania (Negura, 2009), Serbia (Hirt \& Petrović, 2011), Poland (Mostowska, 2009), (East) Germany, and Hungary (Bodnar \& Molnar, 2010).

The existence of GCs as a form of exclusive and segregated neighbourhood has been criticized by various scholars (Low, 2003; Manzi \& Smith-Bowers, 2005; Roitman, 2005). The surrounding walls eliminate the connection to and need for interaction with non-residents (Burke \& Sebaly, 2001), which contradicts government policies to increase social cohesion through continuous linking between neighbourhoods (Grant et al., 2004). GCs also increase the social gap and anxiety among citizens (Low, 2003; Sandercock, 2003) because they symbolize the social inequalities between the upper and lower social classes (Sanchez et al., 2005; Webster et al., 2006). Studies in Malaysia (Xavier, 2008; Lean \& Smyth, 2012) demonstrate that soaring property values contribute significantly to the problem of affordable housing provision as a derivative urban problem of GCs. However, the surrounding walls, security gates, and CCTVs cannot insulate GCs from crime, as is often promised. According to studies in South Africa (Wilson-Doenges, 2000; Duca, 2015), Turkey (Erkip, 2003), and England (Atkinson \& Blandy, 2005), GCs become targets of crime, and the social cohesiveness required for crime prevention is absent. Due to their negative implications, GCs have been demonized with various nicknames, such as fortified enclaves (Caldeira, 2000), exclusive gated worlds of immune communities (Harvey, 1999), quiet and safe havens (Bauman, 2001), dystopias of exclusion (Young, 1999), architectures of fear (Ellin, 1997), and even apartheid architecture (Davis, 1998) to portray the malicious effects of this type of neighbourhood.

Nonetheless, GCs also have positive contributions. They offer an opportunity for better quality of urban design, facilities, and open spaces (Grant et al., 2004). Houses and amenities are designed and developed with a certain set of rules for ensuring the comfort of living in a well-ordered neighbourhood. Public amenities are managed by a private self-governing organization (Glasze et al., 2006). GCs produce shared rules - or private governance, to use Blandy and Lister's (2005) term which are regarded as more efficient and effective neighbourhood management when compared to public management by government. Grant (2005) argues that this private governance minimizes the burden on public management by the government to supply and maintain public amenities. 
Although social ties and cohesion are not the main preference factors of the GC's residents (Blandy \& Lister, 2005), they are developed significantly after living in the neighbourhood (Garip \& Şener, 2012) due to the fact that the residents are living in a confined neighbourhood (Edgü \& Cimşit, 2011) and share the common interest of a relatively homogeneous social class (Xavier, 2008) to support a sense of security (Grant, 2005). Furthermore, a GC is a sanctuary for those who do not follow the established rules or norms in society. For instance, in Saudi Arabia, GCs provide freedom for those who do not agree with the conservative culture on the outside, such as women and expatriates (OdrowazCoates, 2015).

Regardless of the negative implications and positive contributions that GCs share, they are the result of the failure of urban and housing policies to provide a secure and safe living environment (Coy \& Poehler, 2002; Glasze \& Alkhayyal, 2002; Le Goix, 2005; Rosen \& Razin, 2008). Unfortunately, the GC is considered an efficient form of housing development because of developers' involvement in public service provision (Foldvary, 1994). Despite all the problems GCs have caused, many governments such as those in the US (Blakely \& Snyder, 1997; Low, 2003; McKenzie, 2006), Canada (Grant, 2005), and Argentina (Roitman, 2005; Libertun de Duren, 2006) are averse to forestalling the expansion of GCs because they contribute to tax revenues and the provision of public amenities (Grant, 2005; Glasze et al., 2006).

\section{Research method}

In line with its aims, this study uses a qualitative approach and a case study research method. The selected research area is in the Cibubur district, West Java province, Indonesia, because of the good quality of its neighbourhoods and facilities. This GC complex is large, with an area of approximately 480 hectares, with 270 hectares set aside for future development. Since 1997, this GC complex has developed forty-eight housing clusters for approximately 8,700 residents and various facilities such as a market, schools, recreation areas, sports areas, and restaurant, worship, and transportation facilities.

The legislation in force establishes categories of designated residents in mixed-income GCs based on their monthly incomes: below USD 300 for low-income residents, USD $300-600$ and $600-1,000$ for middle-income residents, and above USD 1,000 for affluent residents. The private developer built different types of houses, as defined in the regulations governing mixed-income GCs. Low-income residents are intended to purchase the $21 \mathrm{~m}^{2}$ house type, the first middle income group (USD $300-600$ ) the $36 \mathrm{~m}^{2}$ house type, the second middle income group (USD $600-1,000)$ the $45-60 \mathrm{~m}^{2}$ house type, and the affluent group the largest house type, which averages $120-250 \mathrm{~m}^{2}$.

According to the estate management, before the enactment of Ministry of Public Housing Decree 10/2012, this GC complex built fifteen housing clusters only for middle- and high-income residents. When the regulation was enacted in 2012, only two housing clusters were built in compliance with the decree. Two years later, after enactment of the revised regulation, the rest of the thirty-one housing clusters in the GC complex without low-income housing were mushrooming. This study selected respondents living in the two mixed-income housing clusters, which were built according to Ministry of Public Housing Decree $10 / 2012$, to validate the occurrence of social interaction between social classes in a mixed-income GC.

In order to understand social interaction among residents with different economic statuses, this study examines the reasons for housing selection by residents in different economic strata. It investigates the housing preference factors and the priority of security facilities as the main reasons residents decide to live in a mixed-income GC. Furthermore, this study investigates the usage frequency of the facilities in the GC complex and the frequency of social interaction among residents in the GC in order to understand how often and where social interaction occurred between residents from different economic strata.

Maintaining personal privacy and a lack of interest were the main obstacles to obtaining primary data from GC residents with a door-to-door survey, despite the fact that the estate management and head of the neighbourhood issued survey permits for each housing cluster. Although a survey permit was issued, the estate management demanded anonymity for any publication resulting from this study. Among the 480 residents living in the two mixed-income housing clusters in the GC complex, only eighty-nine respondents participated in this study through snowball sampling.

All four aspects of the study were investigated using a fivepoint Likert scale. This is a prominent analysis instrument in post-occupancy evaluation in many studies worldwide (Hassanain, 2008; Najib et al., 2011; Owolabi, 2015; Eshaghi \& Khozaei, 2016). This study employs this instrument to analyse housing preference factors and the priority of types of security in the GC complex $(1=$ very important to $5=$ least important), as well as the usage frequency of the facilities provided and the frequency of social interaction $(1=$ most frequent to $5=$ least frequent). It was accompanied by semi-structured interviews to investigate the cause of the relationships between the first three aspects and the reasons for social interaction among residents in mixed-income housing clusters. 
Table 1: Housing preference factors by age, sex, and monthly income.

\begin{tabular}{lllllllllll}
\hline Preference factor & General & \multicolumn{2}{l}{ Age (yrs.) } & \multicolumn{3}{l}{ Sex } & \multicolumn{3}{l}{ Monthly income (USD)* } \\
\hline & & $<45$ & $>45$ & $\mathrm{M}$ & $\mathrm{F}$ & $<300$ & $300-600$ & $600-1,000$ & $>1,000$ \\
\hline Security & 1.61 & 1.88 & 1.36 & 1.56 & 1.65 & 2.29 & 2.57 & 2.90 & 4.07 \\
\hline Facility quality/quantity & 1.75 & 1.95 & 1.53 & 1.63 & 1.85 & 1.57 & 2.36 & 1.80 & 2.53 \\
\hline Safety & 2.06 & 2.21 & 1.89 & 2.00 & 2.10 & 2.29 & 3.00 & 2.10 & 2.81 \\
\hline Investment & 2.39 & 2.37 & 2.42 & 2.44 & 2.35 & 2.00 & 2.36 & 2.10 & 2.79 \\
\hline Strategic location & 2.39 & 2.37 & 2.38 & 2.37 & 2.41 & 2.29 & 3.21 & 2.20 & 3.24 \\
\hline House design & 2.49 & 2.63 & 2.38 & 2.34 & 2.63 & 3.43 & 1.71 & 1.10 & 1.72 \\
\hline Social cohesiveness & 2.61 & 2.86 & 2.33 & 2.76 & 2.48 & 2.29 & 2.57 & 1.60 & 1.93 \\
\hline
\end{tabular}

Note: *USD 1 = IRP 15,000

Table 2: Priority of types of security by age, sex, and monthly income.

\begin{tabular}{llllllllll}
\hline Priority of types of security & General & Age & & \multicolumn{3}{l}{ Sex } & \multicolumn{4}{l}{ Monthly income (USD)* } \\
\hline & & $<45$ & $45-65$ & $\mathrm{M}$ & $\mathrm{F}$ & $<300$ & $300-600$ & $600-1,000>1,000$ \\
\hline Security at cluster gate & 1.67 & 1.74 & 1.62 & 1.63 & 1.71 & 2.00 & 2.00 & 1.40 & 2.16 \\
\hline Regular security patrol & 1.75 & 1.91 & 1.62 & 1.63 & 1.85 & 1.57 & 2.36 & 1.60 & 1.66 \\
\hline Security at main gate & 1.91 & 2.00 & 1.84 & 1.76 & 2.04 & 2.29 & 3.64 & 2.20 & 3.02 \\
\hline CCTV in neighbourhood & 2.01 & 2.02 & 2.02 & 1.76 & 2.23 & 2.14 & 2.86 & 2.70 & 3.91 \\
\hline Segregating wall & 2.08 & 2.00 & 2.18 & 1.95 & 2.19 & 2.14 & 1.71 & 1.50 & 2.76 \\
\hline Neighbourhood regulations & 2.19 & 2.33 & 2.09 & 2.00 & 2.35 & 2.00 & 2.14 & 1.50 & 2.62 \\
\hline Security in facilities & 2.55 & 2.72 & 2.40 & 2.60 & 2.50 & 2.57 & 1.71 & 1.30 & 2.02 \\
\hline
\end{tabular}

Note: *USD 1 = IDR 15,000

\section{Findings and discussion}

\subsection{Priority of housing preference factors}

Among the eighty-nine respondents, as shown in Table 1, security (1.61) was the main reason for purchasing and living in the GC, followed by the quality and quantity of facilities (1.75), features in the neighbourhood (2.06), investment considerations (2.39), strategic location (2.39), house design (2.49), and social cohesiveness (2.61). Fear of crime in the neighbourhood was a consideration for the respondents, considering increasing residential criminal activity in Jakarta, such as property theft and child abduction. The availability of facilities was also a preference factor due to the lack of good quality public facilities in the city and the low number of public facilities as well. Furthermore, poor construction of infrastructure and careless drivers in the city create unsafe neighbourhoods, especially for the elderly and children, which makes mixed-income housing clusters in a GC the preferable housing option. Because of the security, facilities, and strategic location, houses in a GC have emerged as a promising investment commodity, regardless of the house design offered. Although it is still regarded as an important preference factor, social cohesiveness is the lowest priority of residents living in the GC.
The residents' highest housing preference factors are security and available facilities (Blakely \& Snyder, 1997). The results for the respondent group under 45 agree with the general results of the survey, whereas the older group shows certain differences. For the older group, social cohesiveness is not the lowest preference factor, but is higher than house design, strategic location, and investment consideration. This finding demonstrates that social cohesiveness within the neighbourhood is still a necessity that must be met in GCs, as argued by some researchers (Edgü \& Cimşit, 2011; Garip \& Şener, 2012).

\subsection{Priority of security facilities}

Table 2 shows that security at the housing cluster gate (1.67) is the main preferred type of security, followed by a regular security patrol (1.75), security at the main gate (1.91), CCTV in the neighbourhood (2.01), a segregating wall with the surrounding neighbourhood (2.08), neighbourhood regulations (2.19), and security in the facilities for the complex residents (2.55).

Although the priorities between the age and sex groups are similar, there are notable differences between the monthly income groups. For respondents with a monthly income less 
Table 3: Usage frequency of facilities provided in the GC complex.

\begin{tabular}{|c|c|c|c|c|c|c|c|c|c|c|}
\hline & & \multicolumn{9}{|c|}{ Facilities in GC complex } \\
\hline & & $\begin{array}{l}\text { China } \\
\text { Village }\end{array}$ & Sport & Food court & Market & Park & Worship & School & Bank & Bus \\
\hline \multirow{2}{*}{ Use for needs } & Frequency & 4.48 & 3.40 & 2.39 & 1.57 & 3.65 & 1.89 & 2.58 & 2.25 & 3.58 \\
\hline & Correlation & .03 & $(.04)$ & .26 & .19 & .11 & .13 & $(.09)$ & .11 & .16 \\
\hline \multirow{2}{*}{$\begin{array}{l}\text { Interact with } \\
\text { others }\end{array}$} & Frequency & 4.84 & 3.79 & 2.84 & 2.01 & 3.69 & 2.02 & 2.96 & 2.84 & 3.89 \\
\hline & Correlation & $(.02)$ & $(.05)$ & .20 & .16 & .09 & .17 & .01 & .19 & .15 \\
\hline
\end{tabular}

than USD 300, a regular security patrol is the highest priority rather than security at the cluster gate because it impedes their family members living outside the GC from visiting. Neighbourhood regulations to increase awareness of security and safety within the cluster has higher priority than security at the main gate and CCTV in the neighbourhood. The first shares the same reason with the security at the cluster, and the second will increase the monthly maintenance fee. In contrast, for the higher income groups (USD $300-600$ and USD 600 - 1,000), exclusive facilities for complex residents are the highest priority. The security and safety aspects are compromised because they are shared with the non-complex residents, whom they barely recognize.

This finding confirms that the priority for types of security is determined by the capacity for crime prevention. Additional technology such as CCTV is the least preferred type of security for most respondents because it increases the monthly expenditure but offers less direct crime prevention. Security at the housing cluster gate and a regular security patrol are the most favourable types of security because of their success with direct crime prevention.

\subsection{Usage frequency of facilities provided in the GC complex}

Table 3 shows that the market (1.57), worship place (1.88), bank (2.25), food court (2.39), and school (2.58) are the most frequently used facilities in this case. In contrast, sport (3.40), bus (3.58), park (3.65), and the China Village recreational area (4.48) are the least frequently used by respondents. Although the availability of facilities is one of the highest preference factors for residents for living in a GC, the correlation with usage frequency is insignificant. This signifies that the facilities provided are the main attractive quality of the mixed-income housing cluster, but the residents do not frequently use the facilities to meet their needs.

According to the interviews, the types of sports facilities provided do not suit the needs of the residents. Most respondents are reluctant to use these facilities because of a mismatch be- tween the types and cost of the sports facilities. Sports facilities, such as the gym and golf course, are not the preferred types for most of them. The respondents prefer communal sports facilities with an affordable cost, such as a swimming pool and sports field. Large numbers of non-resident users, especially on the weekend, also increase the disinclination to use the facilities. A long queue for using equipment in the gym, and noise and crowding inside the facility, create an unpleasant ambiance for residents. It is similar for the shuttle bus, which is mostly used by non-residents to travel to and from their relatives' homes in the GC or to use the facilities. Furthermore, most residents prefer to use their own vehicles rather than the bus.

Although the GC's parks are spacious and have an artistic layout, and the residents appreciate them visually, they are reluctant to use them for weekend picnics or to use any other outdoor facilities. They prefer indoor activities due to the unpleasant humid tropical weather. Although the China Village offers a comfortable space for a tour, it attracts more non-residents than residents. For residents, it is the least necessary facility and they only utilize it to amuse their relatives who stop by, especially children. This finding identifies a discrepancy between the priority of housing preference factors with the usage frequency of the facilities provided. They are the primary housing preference factors of the respondents and why they choose to live in the GC (after security, of course), yet they rarely use the facilities. This occurs because of the mismatch of needs and the lack of exclusivity. The open access allowing non-residents to utilize the facilities has eradicated the sense of a secure, privileged, and prestigious lifestyle, as argued by Blakely and Snyder (1997) and Erkip (2003).

\subsection{Frequency of social interaction among residents in the GC}

Generally, as shown in Table 4, respondents interact or socialize with non-cluster residents (1.97), followed by cluster residents (2.72), non-complex residents (3.61), and complex residents (3.74). This indicates that interaction occurs in the facilities, such as at the market or sports facility, where they meet 
Table 4: Frequency of social interaction among residents in the GC complex.

\begin{tabular}{|c|c|c|c|c|c|c|c|c|c|}
\hline \multirow{2}{*}{$\begin{array}{l}\text { Frequency of social interaction in GC } \\
\text { complex }\end{array}$} & \multirow{2}{*}{ General } & \multicolumn{2}{|l|}{ Age } & \multicolumn{2}{|l|}{ Sex } & \multicolumn{4}{|c|}{ Monthly income (USD)* } \\
\hline & & $<45$ & $45-65$ & M & $\mathrm{F}$ & $<300$ & $300-600$ & $600-1,000$ & $>1,000$ \\
\hline With non-cluster residents & 1.97 & 2.05 & 1.84 & 2.02 & 1.92 & 1.57 & 1.57 & 1.00 & 1.64 \\
\hline With cluster residents & 2.72 & 2.81 & 2.60 & 2.83 & 2.63 & 2.29 & 3.29 & 2.00 & 2.71 \\
\hline With non-complex residents & 3.61 & 3.67 & 3.56 & 3.66 & 3.56 & 3.86 & 2.50 & 1.60 & 2.72 \\
\hline
\end{tabular}

Note: *USD $1=\operatorname{IRP} 15,000$

with various complex residents. The interaction in the cluster neighbourhood occurs when there is a special event, such as an independence day ceremony, voting in the general election, or a wedding or funeral ceremony for a neighbour. Interaction with non-complex residents, who also use facilities such as the market or the sports facilities, has the lowest frequency.

There is a similar ranking in most of the respondent groups by age, by sex, and mostly by monthly income, except for the USD $300-600$ and USD $600-1,000$ groups. These groups have a higher frequency of interaction with non-complex residents than their cluster residents. This occurs in the facilities shared with non-complex resident users and minimizes the possibility of crime occurring within the complex. According to the respondents, this interaction will create social ties between residents and non-residents, which significantly prevents the occurrence of crime and reduces the crime rate within the complex.

This finding contrasts with previous studies, which argue that segregation is the ultimate desire of all the residents living in a GC (Burke \& Sebaly, 2001; Low, 2003; Manzi \& Smith-Bowers, 2005; Roitman, 2005). The enactment of Ministry of Public Housing Decree 10/2012 has successfully minimized the negative effect of segregation in this mixed-income GC complex, but not in the confined housing clusters. This GC is partially porous and penetrable by non-residents.

In the confined housing cluster, the residents rarely interact with each other, unless they are from the same family or the same social group. Different economic strata share major obstacles to social interaction, such as disconnected topics of conversation and feelings of inferiority among others. The residents tend to socially interact with the same economic strata in surrounding clusters, rather than different social classes within their own cluster. To some extent, this confirms the claims of several scholars (Edgü \& Cimşit, 2011; Garip \& Şener, 2012), who optimistically argue that social interaction and cohesiveness grow in mixed-income GCs. However, it introduces a new pattern of trans-cluster homogeneous social class interaction. The mixed-income housing cluster cannot develop shared common interests compared to the relative- ly homogeneous social class, as Xavier (2008) asserts. This indicates that the enactment of Ministry of Public Housing Decree 10/2012 is not working effectively to foster social interaction in mixed-income GCs.

\section{Conclusion}

In order to significantly minimize social segregation, the government encouraged mixed-income housing by enacting Ministry of Public Housing Decree 10/2012 on balanced housing. It is designated to foster social interaction among residents from different economic strata with different monthly incomes. However, it reduces the exclusivity of GCs in terms of the usage of facilities and social class homogeneity. This study shows the ineffectiveness of mixed-income GCs in fostering social interaction among residents from different economic strata.

Security is the main preference factor for the residents of GCs. The poor security and facilities provided by the government are the root of their willingness to live in a GC. They also hope to avoid accidents or crime because the government is unable to provide safety and security for their families. However, the findings of this study also identified a discrepancy between the priority of housing preference factors with usage frequency of the facilities provided. Facilities are the primary housing preference factor among the respondents and the reason they choose to live in a GC, yet they rarely use them. This occurs because of a mismatch of needs and a lack of exclusivity. Therefore, the facilities in the GC fail as a medium to foster social interaction among residents from different economic strata.

Social interaction among residents in the housing cluster also rarely occurs. The different economic strata create different common interests and discourage interaction. Nonetheless, trans-cluster interaction among the same social class is evident in the emergence of social interaction with the same social class beyond the segregated walls. This also provides substantial evidence of the ineffectiveness of mixed-income GCs in fostering social interaction among residents from different economic strata. Therefore, more advanced studies are required to 
foster social cohesiveness among different economic strata in mixed-income GCs. The spatial pattern of social interaction, and high-quality housing and neighbourhood design merit further investigation to minimize the negative implications of GCs in the future. This study also contributes to the improvement of housing policy for creating better mixed-income housing and neighbourhoods in the future.

Maria Lestari Olivia

Department of Architecture, Faculty of Engineering, University of Indonesia (Indon. Universitas Indonesia), Depok City, West Java, Indonesia

E-mail:marialestario@gmail.com

\section{Joko Adianto}

Department of Architecture, Faculty of Engineering, University of Indonesia (Indon. Universitas Indonesia), Depok City, West Java, Indonesia

E-mail: joko.adianto@ui.ac.id

Rossa Turpuk Gabe

Department of Architecture, Faculty of Engineering, University of Indonesia (Indon. Universitas Indonesia), Depok City, West Java, Indonesia

E-mail: rossa@ui.ac.id

\section{Acknowledgments}

We would like to thank the Directorate of Research and Community Engagement, University of Indonesia (Indon. Universitas Indonesia) (DRPM UI), for its financial support under the Hibah Publikasi Internasional Terindeks Tugas Akhir (Hibah PITTA B) Tahun Anggaran 2019 scheme (grant no. NKB-0780/UN2.R3.1/HKP.05.00/2019), and the Faculty of Engineering, University of Indonesia (Indon. Universitas Indonesia) (FTUI), Department of Architecture for their assistance in this research.

\section{References}

Ahmadi, A. (2005) Faktor-faktor yang mempengaruhi perkembangan fisik area pinggiran kota berdasarkan aspek persepsi bermukim pada kota Sengkang Provinsi Sulawesi Selatan. Master's thesis. Semarang, Diponegoro University.

Aris, R. (2003) Perilaku pengembang kecil dalam keputusan investasi di Bandung Raya. Master's thesis. Bandung, Bandung Institute of Technology.

Asiedu, A. B. \& Arku, G. (2009) The rise of gated housing estates in Ghana: Empirical insights from three communities in Metropolitan Accra. Journal of Housing and the Built Environment, 24(3), pp. 227-247. DOI: 10.1007/s10901-009-9146-0

Atkinson, R. \& Blandy, S. (2005) Introduction: International perspective on the new enclavism and the rise of gated communities. Housing Studies, 20(2), pp. 177-186. DOI: 10.1080/0267303042000331718

Atkinson. R. \& Flint, J. (2004) Fortress UK? Gated communities, the spatial revolts of the elites and time-space trajectories of segregation. Housing Studies, 19(6), pp. 875-892.

DOI: $10.1080 / 0267303042000293982$
Bauman, Z. (2001) Community. Seeking safety in an insecure world. Oxford, Polity.

Bekleyen, A. \& Dalkılıç, N. (2011) The influence of climate and privacy on indigenous courtyard houses in Diyarbakır, Turkey. Scientific Research and Essays, 6(4), pp. 908-922. DOI: 10.5897/SRE10.958

Blakely, E. J. \& Snyder, G. M. (1997) Fortress America: Gated communities in the United States. Washington, DC, Brookings Institution Press. DOI: $10.1177 / 000169939804100209$

Blandy, S. (2006) Gated communities in England: Historical perspectives and current developments. GeoJournal, 66(1-2), pp. 15-26. DOI: $10.1007 / \mathrm{s} 10708-006-9013-4$

Blandy, S. \& Lister, D. (2005) Gated communities: (Ne)gating community development? Housing Studies, 20(2), pp. 287-301. DOI: 10.1080/026730303042000331781

Blinnikov, M., Shanin, A., Sobolev, N. \& Volkova, L. (2006) Gated communities of the Moscow green belt: Newly segregated landscapes and the suburban Russian environment. GeoJournal, 66, pp. 65-81. DOI: $10.1007 /$ s10708-006-9017-0

Bodnar, J. \& Molnar, V. (2010) Reconfiguring private and public: State, capital and new housing developments in Berlin and Budapest. Urban Studies, 47(4), pp. 789-812. DOI: 10.1177/0042098009351188

Breetzke, G. D. \& Cohn, E. G. (2013) Burglary in gated communities: An empirical analysis using routine activities theory. International Criminal Justice Review, 23(1), pp. 56-74. DOI: 10.1177/1057567713476887

Burke, M. \& Sebaly, C. (2001) Locking in the pedestrian? The privatised streets of gated communities. World Transport Policy and Practice, 7(4), pp. 67-74.

Caldeira, T. P. R. (1996) Building up walls: The new pattern of spatial segregation in Sao Paulo. International Social Science Journal, 48(1), pp. 55-66. DOI: 10.1111/j.1468-2451.1996.tb00056.x

Caldeira, T. P. R. (2000) City of walls: Crime, segregation, and citizenship in Sao Paulo. Berkeley, University of California Press.

Coy, M. \& Pohler, M. (2002) Gated communities in Latin American megacities: Case studies in Brazil and Argentina. Environment and Planning B: Planning and Design, 29(3), pp. 355-370. DOI: 10.1068/b2772x

Davis, M. (1998) Ecology of fear: Los Angeles and the imagination of disaster. New York, H. Holt.

Dick, H. W. \& Rimmer, P. J. (1998) Beyond the third world city: The new urban geography of South East Asia. Urban Studies, 35(12), pp. 23032321. DOI: $10.1080 / 0042098983890$

Duca, F. (2015) Gating in Johannesburg: Digging inside the social and political system of a golf estate and suburban suburb. In: Bagaeen, S. \& Uduku, O. (eds.) Beyond gated communities: Urban gating and soft boundaries, pp. 49-64. Oxon, UK, Routledge. DOI: $10.4324 / 9781315765976-4$

Dupuis, A. \& Thorns, D. (2008) Gated communities as exemplars of "forting up" practices in a risk society. Urban Policy and Research, 26(2), pp. 145-157. DOI: 10.1080/08111140802026800

Edgü, E. \& Cimşit, F. (2011) Island living as a gated community: Place attachment in an isolated environment. A|Z ITU Journal of the Faculty of Architecture, 8(2), pp. 156-177.

Ellin, N. (1997) Architecture of fear. New York, Princeton Architectural Press.

Erkip, F. (2003) The shopping mall as an emergent public space in Turkey. Environment and Planning A: Economy and Space, 35(6), pp. 10731093. DOI: $10.1068 / a 35167$ 
Eshaghi, A., Khozaei, F. (2015) Learning from architects' mistakes, a case study of three female students residence halls. Specialty Journal of Architecture and Construction, 1(3), pp. 17-21.

Febby, A. (2010) Preferensi penghuni perumahan di kota Pekanbaru dalam menentukan lokasi perumahan. Jurnal Ekonomi Pembangunan, 12(1), pp. 77-91. DOI: 10.23917/jep.v12i1.207

Firman, T. (2004) New town development in Jakarta metropolitan region: A perspective of spatial segregation. Habitat International, 28(3), pp. 349-368. DOI: 10.1016/S0197-3975(03)00037-7

Foldvary, F. (1994) Public goods and private communities: The market provision of social services. Aldershot, UK, Edward Elgar.

Garip, S. B. \& Sener, H. (2012) Analysing environmental satisfaction in gated housing settlements: A case study in Istanbul. A|Z ITU Journal of the Faculty of Architecture, 9(1), pp. 120-131.

Ginting, S. W. \& Sakinah, R. (2018) Gated community in Indonesian peri-urban: Security or segregation? IOP Conf. Series: Earth and Environmental Science, 202(1), pp. 1-10. DOI: 10.1088/1755-1315/202/1/012057

Glasze, G. \& Alkhayyal, A. (2002) Gated housing estates in the Arab world: Case studies in Lebanon and Riyadh, Saudi Arabia. Environment and Planning B: Planning and Design, 29(3), pp. 321-336.

DOI: $10.1068 / \mathrm{b} 12825 \mathrm{t}$

Glasze, G., Webster, C. \& Frantz, K. (2006) Private cities: Global and local perspectives. London, Routledge.

Gleeson, B. (2006) Australia's heartlands: Making space for hope in the suburbs. Crows Nest, NSW, Allen \& Unwin.

Gooblar, A. (2002) Outside the walls: Urban gated communities and their regulation within the British planning system. European Planning Studies, 10(3), pp. 321-334. DOI: 10.1080/09654310220121068

Grant, J. (2005) Planning responses to gated communities in Canada. Housing Studies, 20(2), pp. 273-285.

DOI: $10.1080 / 026730303042000331772$

Grant, J., Greene, K. \& Maxwell, K. (2004) The planning and policy implications of gated communities. Canadian Journal of Urban Research, 13(1), pp. 70-88. Available at: http://www.jstor.org/stable/44321057 (accessed 20 Feb. 2019)

Grant, J. \& Mittelsteadt, L. (2004) Types of gated communities. Environment and Planning B: Planning and Design, 31(6), pp. 913-930. DOI: $10.1068 / \mathrm{b} 3165$

Hackworth, J. (2007) The neoliberal city: Governance, ideology, and development in American urbanism. Ithaca, NY, Cornell University Press. DOI: 10.7591/9780801461590

Handoko, J. P. S. (2011) Pertumbuhan permukiman gated community di Yogyakarta: Perumahan-perumahan di Kabupaten Sleman Yogyakarta. Yogyakarta, Proceeding Seminar Nasional SCAN\#2 Lifestyle and Architecture. DOI: 10.13057/psnmbi/m010419

Harvey, D. (1999) Justice, nature \& the geography of difference. Oxford, Blackwell.

Hassanain, M. A. (2008) On the performance of evaluation on sustainable student housing facilities, Journal of Facilities Management, 6(3), pp. 212-225. DOI: 10.1108/14725960810885989

Hirt, S. A. (2012) Iron curtains. Gates, suburbs and privatization of space in the post-socialist city. Chichester, UK, Wiley-Blackwell. DOI: 10.1002/9781118295922

Hirt, S. A. \& Petrović, M. (2011) The Belgrade wall: The proliferation of gated housing in the Serbian capital after socialism. International Journal of Urban and Regional Research, 35(4), pp. 753-777. DOI: 10.1111/j.1468-2427.2011.01056.x
Hishiyama, K. (2010) Uneasy society in Indonesia: With special attention to the gated community and CCTV in Bali, Procedia Social and Behavioral Sciences, 2(1), pp. 14-23. DOI: 10.1016/j.sbspro.2010.01.006

Kartiwa, A. (2016) Jaringan pengembang perumahan skala besar di Jabodetabek. Master's thesis. Bandung, Bandung Institute of Technology.

King, A. D. (2004) Spaces of global cultures: Architecture urbanism identity. New York, Routledge.

Kuppinger, P. (2008) Exclusive greenery: New gated communities in Cairo. City \& Society, 16(2), pp. 35-61. DOI: 10.1525/city.2004.16.2.35

Landman, K. \& Schonteich, M. (2002) Urban fortresses. Gated communities as a reaction to crime. African Security Review, 11(4), pp. 71-85. DOI: 10.1080/10246029.2002.9628147

Le Goix, R. (2005) Gated communities: Sprawl and social segregation in southern California. Housing Studies, 20(2), pp. 323-344. DOI: $10.1080 / 026730303042000331808$

Leaf, M. (1993) Land rights for residential development in Jakarta, Indonesia: The colonial roots of contemporary urban dualism. International Journal of Urban and Regional Research, 17(4), pp. 477-491. DOI: $0.1111 / \mathrm{j} .1468-2427.1993 . \mathrm{tb} 00236 . x$

Leaf, M. (1994) The suburbanization of Jakarta: A concurrence of economics and ideology. Third World Planning Review, 16(4), pp. 341-356. DOI: 10.3828/twpr.16.4.n51557k1532xp842

Lean, H. H. \& Smyth, R. (2013) Regional house prices and the ripple effect in Malaysia. Urban Studies, 50(5), pp. 895-922. DOI: $10.1177 / 0042098012459582$

Lee, S. \& Webster, C. (2006) Enclosure of the urban commons. GeoJournal, 66(1/2), pp. 27-42. DOl: 10.1007/s10708-006-9014-3

Leisch, H. (2002) Gated communities in Indonesia. Cities, 19(5), pp. 341350. DOI: 10.1016/S0264-2751(02)00042-2

Libertun de Duren, N. R. (2006) Planning a la carte: The location patterns of gated communities around Buenos Aires in a decentralized planning context. International Journal of Urban and Regional Research, 30(2), pp. 308-327. DOI: 10.1111/j.1468-2427.2006.00667.x

Low, S. (2003) Behind the gates: Life, security and the pursuit of happiness in fortress America. New York, Routledge. DOI: $10.4067 / \mathrm{s} 0250-71612003008700008$

Low, S. M. (2001) The edge and the center: Gated communities and the discourse of urban fear. American Anthropologist, 103(1), pp. 45-58. DOI: 10.1525/aa.2001.103.1.45

Manzi, T. \& Smith-Bowers, B. (2005) Gated communities as club goods: Segregation or social cohesion? Housing Studies, 20(2), pp. 345-359. DOI: $10.1080 / 0267303042000331817$

McKenzie, E. (2003) Common-interest housing in the communities of tomorrow. Housing Policy Debate, 14(1\&2), pp. 203-234. DOI: 10.1080/10511482.2003.9521473

McKenzie, E. (2006) The dynamics of privatopia: Private residential governance in the USA. In: Glasze, G., Webster, C. \& Frantz, K. (eds.) Private cities: Global and local perspectives, pp. 9-30. London, Routledge.

Mostowska, M. (2009) Provision of private services and enforcing neighbours' behaviour in one of Warsaw's gated neighborhoods. In: Smigiel, C. (ed.) Gated and guarded housing in Eastern Europe, pp. 69-74. Leipzig, Leibniz-Institut für Länderkunde.

Najib, N. U. M., Yusof, N. A., \& Abidin, N. Z. (2011) Student residential satisfaction in research universities. Journal of Facilities Management 9(3), pp. 200-212. DOI: 10.1108/14725961111148108 
Negura, O. (2009) Residential ensembles in "hypermodern times". A case study of their aspirations in Bucharest. In: Smigiel, C. (ed.) Gated and guarded housing in Eastern Europe, pp. 59-68. Leipzig, Leibniz-Institut für Länderkunde.

Nurhadi, I (2004) Preferensi masyarakat dalam memilih perumahan perkotaan di kota Tangerang studi kasus: Perumahan Banjar Wijaya, Poris Indah, dan Perumnas IV. Master's thesis. Semarang, Universitas Diponegoro. DOI: 10.31848/arcade.v1i2.16

Odrowaz-Coates, A. (2015) A gated community as a "soft" and gendered total institution. International Sociology, 30(3), pp. 233-249. DOI: $10.1177 / 0268580915578759$

Owolabi, B. O. (2015) The effects of students' housing on academic performance at the University of Ibadan in Nigerian. International Journal of Scientific \& Engineering Research, 6(3), pp. 1118-1132.

Parker, S. (2006) Theory of urban experience. Bologna, II Mulino.

Pow, C.-P. (2007a) Securing the "civilised" enclaves: Gated communities and the moral geographies of exclusion in (post)-socialist Shanghai. Urban Studies, 44(8), pp. 1539-1558. DOI: 10.1080/00420980701373503

Pow, C.-P. (2007b) Constructing a new private order: Gated communities and the privatization of urban life in post-reform Shanghai. Social and Cultural Geography, 8(6), pp. 813-833. DOI: 10.1080/14649360701712511

Pow, C.-P. (2009) Public intervention, private aspiration: Gated communities and the condominisation of housing landscapes in Singapore. Asia Pacific Viewpoint, 50(2), pp. 215-227.

DOI: 10.1111/j.1467-8373.2009.01394.x

Pribadi, D.O \& Pauleit, S. (2016) Peri-urban agriculture in Jabodetabek Metropolitan Area and its relationship with the urban socioeconomic system. Land Use Policy, 55, pp. 256-274. DOI: 10.1016/j.landusepol.2016.04.008

Quintal, D. (2006) Gated communities in Sydney: A search for security. Bachelor's thesis. New South Wales, University of New South Wales.

Raposo, R. (2006) Gated communities, commodification and aestheticization: The case of the Lisbon metropolitan area. GeoJournal, 66(1-2), pp. 43-56. DOI: 10.1007/s10708-006-9015-2

Remali, A. M. \& Salama, A. M. (2016) A chronological exploration of the evolution of housing typologies in Gulf cities. City Territory and Architecture, 3(14), pp. 1-15. DOI: 10.1186/s40410-016-0043-z

Rizzo, A. (2014) Rapid urban development and national master planning in Arab Gulf countries. Qatar as a case study. Cities, 39, pp. 50-57. DOI: 10.1016/j.cities.2014.02.005

Roitman, S. (2005) Who segregates whom? The analysis of a gated community in Mendoza, Argentina. Housing Studies, 20(2), pp. 303-321. DOI: 10.1080/026730303042000331790

Rosen, G. \& Razin, E. (2008) The rise of gated communities in Israel: Reflections on changing urban governance in a neo-liberal era. Urban Studies, 46(8), pp. 1702-1722. DOI: 10.1177/0042098009105508

Rudiawan, R. (2008) Kajian pengembangan wilayah dan implikasinya terhadap bisnis dan investasi properti di Kabupaten Bandung Barat. Bandung, Bandung Institute of Technology. Bandung, Bandung Institute of Technology.

Ruoppila, S. \& Kaehrik, A. (2003) Socio-economic residential differentiation in post-socialist Tallinn. Journal of Housing and the Built Environment, 18(1), pp. 49-73. DOI: 10.1023/A:1022435000258
Salcedo, R. \& Torres, A. (2004) Gated communities in Santiago: Wall or frontier. International Journal of Urban and Regional Research, 28(1), pp. 27-44. DOI: 10.1111/j.0309-1317.2004.00501.x

Sanchez, T. W., Lang, R. E. \& Dhavale, D. M. (2005) Security versus status? A first look at the census's gated community data. Journal of Planning Education and Research, 24(3), pp. 281-291. DOI: 10.1177/0739456X04270127

Sandercock, L. (2003) Cosmopolis II: Mongrel cities of the 21st Century. London, Continuum.

Stoyanov, P. \& Frantz, K. (2006) Gated communities in Bulgaria: Interpreting a new trend in post-communist urban development. GeoJournal, 66(1-2), pp. 57-63. DOI: 10.1007/s10708-006-9016-1

Sueca, N. P. \& Fitriani, L. R. D. (2012) Profile gated community di Denpasar. Prosiding Temu IImiah IPLBI, pp. 45-48. Bandung, Bandung Institute of Technology.

Tambunan, D. B. (2009) Atribut yang menjadi pertimbangan konsumen dalam membeli produk perumahan: Penelitian dan analisis conjoint. Jurnal Manajemen Bisnis, 2(2), pp. 141-153.

Thuillier, G. (2005) Gated communities in the metropolitan area of Buenos Aires, Argentina: A challenge for town planning. Housing Studies, 20(2), pp. 255-271. DOI: 10.1080/026730303042000331763

Townshend, I. J. (2006) From public neighborhoods to multi-tier private neighborhoods: The evolving ecology of neighbourhood privatization in Calgary. GeoJournal, 66, pp. 103-120.

DOI: 10.1007/s10708-006-9010-7

Webster, C, Wu, F. \& Zhao, Y. (2006) China's modern gated cities. In: Glasze, G., Webster, C. \& Frantz, K. (eds). Private communities: Global and local perspectives, pp. 153-169. Oxford, Routledge.

Wilson-Doenges, G. (2000) An exploration of sense of community and fear of crime in gated communities. Environment and Behavior, 32(5), pp. 597-611. DOI: 10.1177/00139160021972694

Winarso, H. (2005) City for the rich. In: Cities of People: Papers of the 8th International Conference of the Asian Planning Schools Association Held on 11-14 September 2005 in Penang, pp. 11-14. Penang, International Conference of the Asian Planning Schools Association.

Winarso, H., Hudalah, D. \& Firman, T. (2015) Peri-urban transformation in the Jakarta metropolitan area. Habitat International, 49, pp. 221-229. DOI: 10.1016/j.habitatint.2015.05.024

Wu, F. (2005) Rediscovering the "gate" under market transition: From work-unit compounds to commodity housing enclaves. Housing Studies, 20(2), pp. 235-254. DOI: 10.1080/026730303042000331754

Wu, F. \& Webber, K. (2004) The rise of "foreign gated communities" in Beijing: Between economic globalization and local institutions. Cities, 21(3), pp. 203-213. DOI: 10.1016/j.cities.2004.03.002

Xavier, G. (2008) Gated and guarded communities-security concerns for elitist practice? Paper presented at the 5th Asian Law Institute Conference, 22-23 May, Singapore. Typescript.

Young, J. (1999) The exclusive society: Social exclusion, crime and difference in late modernity. London, Sage.

Zaina, S., Zaina S. \& Furlan, R. (2016) Urban planning in Qatar: Strategies and vision for the development of transit villages in Doha. Australian Planner, 53(4), pp. 286-301. DOI: 10.1080/07293682.2016.1259245 